\title{
Metabolism and lactation performance in dairy cows fed a diet containing rumen-protected fat during the last twelve weeks of gestation
}

\author{
K. Duske, ${ }^{*}$ H. M. Hammon, ${ }^{*}$ A.-K. Langhof, ${ }^{*}$ O. Bellmann, ${ }^{*}$ B. Losand,† K. Nürnberg, ${ }^{*}$ G. Nürnberg, $\dagger$ \\ H. Sauerwein, $\ddagger$ H. M. Seyfert, ${ }^{*}$ and C. C. Metges ${ }^{* 1}$ \\ ${ }^{*}$ Research Institute for the Biology of Farm Animals (FBN), 18196 Dummerstorf, Germany \\ †State Institute of Animal Production, 18196 Dummerstorf, Germany \\ łInstitute of Animal Science, Physiology \& Hygiene Unit, Rheinische Friedrich-Wilhelm University, 53115 Bonn, Germany
}

\begin{abstract}
Effects of dietary fat supplementation prepartum on liver lipids and metabolism in dairy cows are contradictory. Thus, we examined in 18 German Holstein cows (half-sib; first lactation 305-d milk yield $>9,000 \mathrm{~kg}$ ) whether dietary fat:carbohydrate ratio during the last trimester of gestation affects lipid metabolism and milk yield. The diets were formulated to be isoenergetic and isonitrogenous but differed in rumen-protected fat (FD; 28 and $46.5 \mathrm{~g} / \mathrm{kg}$ of dry matter during far-off and closeup dry period; mainly $\mathrm{C} 16: 0$ and $\mathrm{C} 18: 1)$ and starch concentration [carbohydrate diet (CD); 2.3 times as much starch as FD]. Diets were given ad libitum starting $12 \mathrm{wk}$ before expected parturition. After parturition all cows were fed a single lactation diet ad libitum for 14 wk. With the FD treatment, dry matter intake was depressed prepartum, milk yield during first 4 wk of lactation was lower (36.9 vs. $41.0 \mathrm{~kg} / \mathrm{d}$ ), and postpartum energy balance during this period was more negative. During the first $4 \mathrm{wk}$, cows in the FD group had lower lactose percentage and yield but higher milk fat, whereas milk protein and fat yield as well as energycorrected milk did not differ. Between wk 5 and 14, milk fat and milk protein percentage was lower in CD than in FD. Milk fat C14:0 was lower and C16:1 was higher in the FD group. For FD cows, plasma triacylglycerol, nonesterified fatty acids, and cholesterol concentrations were higher prepartum, whereas plasma $\beta$-hydroxybutyrate and glucose concentrations were lower. During the first $10 \mathrm{~d}$ after parturition, plasma triacylglycerol concentration was higher in FD, and prepartum plasma glucose and cholesterol differences persisted during the first $14 \mathrm{wk}$ of lactation. Irrespective of prepartum nutrient composition, concentrations of plasma leptin and subcutaneous fat leptin mRNA decreased between $-10 \mathrm{~d}$ to $+10 \mathrm{~d}$ relative to parturi-
\end{abstract}

Received July 11, 2008.

Accepted November 28, 2008.

${ }^{1}$ Corresponding author: metges@fbn-dummerstorf.de tion, and liver lipids and glycogen reached maximum and minimal values, respectively, $10 \mathrm{~d}$ after parturition. Acetyl-coenzyme A carboxylase $\alpha$ mRNA abundance in subcutaneous fat decreased between $-10 \mathrm{~d}$ to $+1 \mathrm{~d}$ relative to parturition by $97 \%$, whereas it was generally much lower in the liver and remained at a low level until wk 14 of lactation. In conclusion, feeding a diet containing rumen-protected fat during late lactation and dry period until calving negatively affected dry matter intake, energy balance, and milk yield during subsequent lactation, did not change acetyl-coenzyme A carboxylase $\alpha$ mRNA abundance in subcutaneous fat, and was not beneficial for liver lipid accumulation. Key words: rumen-protected fat, dairy cow, lipid metabolism, dry period

\section{INTRODUCTION}

The transition period of dairy cows is usually defined as the period from about 3 wk precalving to 3 wk postcalving and is of paramount importance for health and profitability (Grummer, 1995). This part of the lactation cycle is most important because of the sudden and profound physiological and metabolic changes in the course of transition from pregnancy to lactation. Regulation and coordination of lipid metabolism are key components of the adaptation to lactation (Drackley, 1999). During the first weeks of lactation, energy intake (EI) in high-yielding dairy cows is not sufficient to meet requirements for milk production and maintenance. Consequently, cows mobilize body energy stores in an attempt to counteract the energy deficit. Extensive mobilization of body fat is the most important factor for developing metabolic disorders such as fatty liver and ketosis (Vernon, 2005; Goff and Horst, 1997) due to a reduced ability to eliminate fatty acids (FA) via $\beta$-oxidation or export triacylglycerols (TAG) in the form of very low density lipoproteins (VLDL) from the liver (Grummer, 1993; Bell, 1995). There is large body of work showing that FA feeding in lactating dairy cows improves milk yield and milk fat 
and energetic efficiency, and decreases milk protein and lipogenesis (Chilliard et al., 1991; Coppock and Wilks, 1991; Palmquist et al., 1993; McNamara et al., 1995; Jenkins and McGuire, 2006). In most of the studies, FA were supplied during early, mid, or mid to late lactation (Grummer et al., 1995; McNamara et al., 1995; Vazquez-Anon et al., 1997) or from a few days precalving to several weeks after calving (Moallem et al., 2007a,b; Petit et al., 2007; Van Knegsel et al., 2007). However, few studies examined the influence of dietary fat supplied solely during dry period, and during late lactation plus the dry period on lactation performance and metabolic changes during the following lactation. Cows supplemented with fat during between 60 until $7 \mathrm{~d}$ before calving had lower hepatic lipid contents at parturition in comparison to cows fed a control or a high-grain diet, which suggests that cows fed fat prepartum might not be predisposed for fatty liver syndrome (Grum et al., 1996). Fat supplementation during the whole dry period failed to affect peripartal lipid content in liver (Douglas et al., 2004, 2006). In contrast, others reported that hepatic lipid accumulation tended to increase at parturition by supplementation of fat $17 \mathrm{~d}$ prepartum (Skaar et al., 1989). Vazquez-Añon et al. (1997) found even elevated liver triglycerides at d 1 after parturition in cows fed high-fat diets for $19 \mathrm{wk}$ during the previous mid to late lactation.

Acetyl-coenzyme A carboxylase alpha (ACC $\boldsymbol{\alpha}$ ) plays an important role in FA synthesis as well as in FA oxidation. It has been shown in rats that upon parturition, mammary gland transcript level of ACC $\alpha$ increases dramatically, whereas it decreases simultaneously in adipose tissue, with levels in liver being the lowest and changing only moderately (Ponce-Castaneda et al., 1991). Less information is available on the effect of macronutrient ratio on tissue-specific abundance of $\mathrm{ACC} \alpha \mathrm{mRNA}$ species in the periparturient cow (Sumner et al., 2008). Fat feeding increased or decreased plasma leptin concentration in rats (Cha and Jones, 1998; Ainslie et al., 2000) and did not change leptinemia in lactating cows fed fat during the transition period (Becu-Villalobos et al., 2007). Leptin receptor mRNA levels in adipose tissue were reported for male calves, prepubertal heifers, and late lactating cows but not for periparturient cows (Chelikani et al., 2003; Bernabucci et al. 2006; Thorn et al., 2007).

To investigate effects of fat feeding prepartum, we studied the immediate and long-term effects of a diet containing rumen-protected fat, fed throughout the last 12 wk of gestation in cows during their transition to second lactation on milk yield, EI, metabolic status, and transcript levels of leptin, leptin receptor, and $\mathrm{ACC} \alpha$ species in s.c. fat and liver, respectively.

\section{MATERIALS AND METHODS}

\section{Cows and Diets}

The experimental protocol was approved by the relevant authorities (Landesamt für Landwirtschaft, Lebensmittelsicherheit und Fischerei MecklenburgVorpommern; LALLF M-V/TSD/7221.3-1.1-048/05; LALLF M-V/TSD/7221.3-1.2-008/06). Eighteen German Holstein cows, with comparable milk production (first lactation $>9,000 \mathrm{~kg}$ of milk in $305 \mathrm{~d}$ ), were purchased from a local farm (Demmin, Germany) after about 300 DIM and were allocated to 2 feeding groups ( $\mathrm{n}=9$ /group). All cows were daughters of dams inseminated by sperm of the same bull, and thus half-sisters. For logistic reasons, 3 cows in each group (total of 6 cows) were investigated during the same time period (block). Allocation was carried out randomly, but care was taken that average milk yield during the first 100 $\mathrm{d}$ of the first lactation, gestation stage, and BW did not differ among groups. Twelve weeks before expected parturition, cows received 1 of 2 diets differing in fat content [fat-accentuated diet (FD), carbohydrate-based diet (CD)] but formulated to be isonitrogenous and isoenergetic (Table 1). Eight weeks before expected parturition, cows were ceased to be milked, administered dry period antibiotics (Nafpenzal, Intervet, Unterschleißheim, Germany), and received a far-off and a close-up diet during wk 8 to 4 and from wk 3 to parturition, respectively, differing in fat:carbohydrate ratio (Table 1). The rumen-protected fat (Hajenol, Harles und Jentzsch GmbH, Uetersen, Germany) used consisted of $\mathrm{Ca}$ salts with mainly palmitic and oleic acid, and its apparent digestibility was $78.3 \%$ (Voigt et al., 2006). After parturition, all cows were fed the same lactation diet (LD). Diets were fed ad libitum as TMR at 0600 and $1500 \mathrm{~h}$. The cows were milked twice daily at 0500 and $1600 \mathrm{~h}$ and housed in a pen with individual troughs placed on scales (Bayerische Landesanstalt für Landwirtschaft, Institut für Landtechnik, Bauwesen und Umwelttechnik, Freising, Germany) to monitor individual feed intake. Between $10 \mathrm{~d}$ before until $1 \mathrm{~d}$ after birth, cows were housed in calving boxes with straw. They were then moved to a tie-box until d 5 of lactation and subsequently returned to the pen.

Energy balance of cows was calculated as follows:

$$
\begin{aligned}
& \mathrm{EB}=\mathrm{EI}\left(\mathrm{MJ} \text { of } \mathrm{NE}_{\mathrm{L}} / \mathrm{d}\right)-[\text { maintenance energy } \\
& \text { requirement }\left(\mathrm{MJ} \text { of } \mathrm{NE}_{\mathrm{L}} / \mathrm{d}\right) \\
& \left.+ \text { milk energy }\left(\mathrm{MJ} \mathrm{NE}_{\mathrm{L}} / \mathrm{d}\right)\right] \text {, }
\end{aligned}
$$

where maintenance energy ( $\mathrm{MJ}$ of $\mathrm{NE}_{\mathrm{L}} / \mathrm{d}$ ) was calculated as $0.293 \times \mathrm{BW}^{0.75}$ and milk energy $\left(\mathrm{MJ}\right.$ of $\mathrm{NE}_{\mathrm{L}} / \mathrm{d}$ ) 
Table 1. Ingredients and chemical composition of fat supplemented (FD), carbohydrate-based (CD), and lactation (LD) diets fed to cows before and after parturition

\begin{tabular}{|c|c|c|c|c|c|}
\hline \multirow[b]{2}{*}{ Item } & \multicolumn{2}{|c|}{ Far-off } & \multicolumn{2}{|c|}{ Close-up } & \multirow{2}{*}{$\frac{\text { Second lactation }^{1}}{\mathrm{LD}}$} \\
\hline & $\mathrm{CD}$ & FD & $\mathrm{CD}$ & FD & \\
\hline \multicolumn{6}{|c|}{ Ingredient, $\%$ of DM } \\
\hline Grass silage & 76.2 & 77.5 & 29.4 & 32.5 & 17.3 \\
\hline Corn silage & & & 17.9 & 18.9 & 1.5 \\
\hline Dried pulp & & & 17.7 & 18.6 & 12.8 \\
\hline Straw $^{2}$ & 17.3 & 20.0 & 10.6 & 11.1 & 1.1 \\
\hline Byoprofin $^{4}$ & & & & & 4.0 \\
\hline Barley meal & & & & & 13.5 \\
\hline Soybean meal & & & 12.9 & 13.6 & 15.1 \\
\hline Grass hay & & & & & 1.4 \\
\hline S-Lactal $^{5}$ & & 0.96 & 0.95 & 0.66 & 0.87 \\
\hline Limestone & & & 0.16 & & 0.42 \\
\hline Propylene glycol & & & & & 0.99 \\
\hline $\mathrm{NE}_{\mathrm{L}}^{6}$ & 5.8 & 5.9 & 6.8 & 7.2 & 7.2 \\
\hline
\end{tabular}

${ }^{1}$ From calving to 95 DIM.

${ }^{2}$ Straw was chopped at 1 - to 2 -cm length.

${ }^{3} \mathrm{Hajenol}$ was a gift of Harles and Jentzsch GmbH (Uetersen, Germany) and contained $840 \mathrm{~g} / \mathrm{kg}$ of DM crude fat (1.5\% myristic acid, $44 \%$ palmitic acid, $5 \%$ stearic acid, $40 \%$ oleic acid, and $9.5 \%$ linoleic acid), $20.2 \mathrm{MJ}$ of $\mathrm{NE}_{\mathrm{L}} / \mathrm{kg}$ of DM, $120 \mathrm{~g} / \mathrm{kg}$ of $\mathrm{DM}$ crude ash, and $95 \mathrm{~g} / \mathrm{kg}$ of DM calcium.

${ }^{4}$ Byoprofin (Wulfa-Mast GmbH, Dinklage, Germany); protection of extracted soybean meal was through formaldehyde treatment.

${ }^{5}$ S-Lactal (Spezialfutter Neuruppin GmbH \& Co. KG, Neuruppin, Germany).

${ }^{6} \mathrm{In} \mathrm{MJ}$ of $\mathrm{NE}_{\mathrm{L}}$ per $\mathrm{kg}$ of $\mathrm{DM}$.

$=$ milk $(\mathrm{kg} / \mathrm{d}) \times[0.95+0.38 \times$ fat $\%+0.21 \times$ protein

\%] (German Society of Nutrition Physiology, 2001).

\section{Tissue and Blood Sampling and Measurement of Zootechnical Variables}

Liver and s.c. fat biopsies were taken $10 \mathrm{~d}$ before expected parturition and $1,10,28$, and $95 \mathrm{~d}$ after parturition to determine liver fat and glycogen content and liver and s.c. fat mRNA abundance. The biopsy areas were clipped and disinfected. Before biopsy, the animals were sedated with $1 \mathrm{~mL}$ of Xylazin $2 \%$ (Serumwerk Bernburg AG, Bernburg, Germany). Before sampling, the skin area around the 12th intercostal space was locally anaesthetized with $1 \mathrm{~mL}$ of Lidocain $2 \%$ (Serumwerk Bernburg AG) for liver biopsies, whereas for fat biopsies, a $10 \times 10 \mathrm{~cm}$ skin area on the back approximately $10 \mathrm{~cm}$ behind the withers was locally anaesthetized with $10 \mathrm{~mL}$ of Lidocain $2 \%$ (Serumwerk Bernburg AG). After cutting the skin, liver tissue (ca. $1 \mathrm{mg}$ ) was extracted using a tailor-made biopsy needle (diameter $6 \mathrm{~mm}$ ), and s.c. fat tissue was scraped with a sterile scalpel from the designated area. All tissue samples were immediately frozen in liquid nitrogen and stored at $-80^{\circ} \mathrm{C}$ until analyzed.
Jugular blood samples were obtained by venipuncture at termed intervals pre- and postpartum until 95 $\mathrm{d}$ after parturition. Samples were taken at $0900 \mathrm{~h}$ and immediately before biopsy if both sampling time points fell on the same day. Blood was collected in vacutainers (Vacuette, Greiner Bio-One, Kremsmünster, Austria) containing EDTA for determination of TAG, NEFA, BHBA, cholesterol, glucose, and leptin. Blood samples for plasma preparation were stored on ice directly after withdrawal and were centrifuged 30 min later. All samples were centrifuged at $4^{\circ} \mathrm{C}$ and $1,500 \times g$ for 20 min. Aliquots were stored at $-20^{\circ} \mathrm{C}$ until analysis.

Backfat thickness (BFT) was measured according to Schröder and Staufenbiel (2006) at an imaginary line between the hooks and pins at the sacral examination site once weekly by ultrasound (Aloka SSK-500, PPG Hellige GmbH, Freiburg, Germany). Body weight was also measured once weekly after the morning milking.

\section{Feed and Milk Sampling and Analysis}

Samples from complete TMR were taken monthly and stored at $-20^{\circ} \mathrm{C}$ for determination of nutrient composition at the Landwirtschaftliche Untersuchungs- und Forschungsanstalt, Rostock, analyzed by the Weender 
standard procedure (Naumann and Bassler, 1993). For determination of DM, samples of grass and corn silage were taken weekly and dried at $60^{\circ} \mathrm{C}$ for $24 \mathrm{~h}$ and subsequently at $105^{\circ} \mathrm{C}$ for $3 \mathrm{~h}$.

Milk aliquots were collected once weekly during morning milking for determination of fat, protein, and lactose contents and the composition of FA. Determination of milk fat, protein, lactose, and SCC in milk was performed by the Landeskontrollverband für Leistungsund Qualitätsprüfung Mecklenburg-Vorpommern e.V., Güstrow, Germany, using an infrared spectrophotometric method (Milcosan, Foss Germany, Rellingen, Germany).

Yield of ECM was calculated as follows:

$$
\begin{gathered}
\text { ECM }(\mathrm{kg})=[(0.38 \times \mathrm{g} \text { of crude fat }+0.24 \\
\quad \times \mathrm{g} \text { of } \mathrm{CP} \times 0.17 \mathrm{~g} \text { of lactose }) \\
\times \mathrm{kg} \text { of milk }] / 3.14 \text { (Reist et al., } 2003) .
\end{gathered}
$$

Milk FA composition was determined in extracted milk fat. Twenty milliliters of n-hexane/isopropanol $(3: 2 \mathrm{vol} / \mathrm{vol})$ and $10 \mathrm{mg}$ of internal standard (C19:0 TAG) were added to $10 \mathrm{~mL}$ of milk and kept for $1 \mathrm{~h}$ at room temperature. The upper layer was combined with $\mathrm{Na}_{2} \mathrm{SO}_{4}$, filtered, evaporated under $\mathrm{N}_{2}$, and sodium methoxide and $\mathrm{BF}_{3} / \mathrm{MeOH}(14 \%$, wt/vol) were added to prepare FA methyl esters (FAME). The FAME were extracted twice, the upper layers containing FAME were pooled, and the solvent was evaporated under $\mathrm{N}_{2}$. The FAME were redissolved in $150 \mu \mathrm{L}$ of n-hexane and stored at $-20^{\circ} \mathrm{C}$ until analysis. The FA composition was determined by gas chromatography (Perkin Elmer GC Autosys XL, Waltham, MA) on a capillary column (CP SIL 88, $100 \mathrm{~m} \times 0.25 \mu \mathrm{m}$; Chrompack, Varian,
Palo Alto, CA) with a flame ionization detector and split injection. The split ratio was 1:25, the injector was set at $260^{\circ} \mathrm{C}$, and the detector at $280^{\circ} \mathrm{C}$. Initial oven temperature was $120^{\circ} \mathrm{C}$, held for 5 min, subsequently increased to $170^{\circ} \mathrm{C}$ at a rate of $2^{\circ} \mathrm{C} / \mathrm{min}$, held for 15 min, then to $200^{\circ} \mathrm{C}$ at $5^{\circ} \mathrm{C} / \mathrm{min}$, held for $5 \mathrm{~min}$, then to $235^{\circ} \mathrm{C}$ at $2^{\circ} \mathrm{C} / \mathrm{min}$, and held for $10 \mathrm{~min}$. Hydrogen (flow rate of $1 \mathrm{~mL} / \mathrm{min}$ ) was used as the carrier gas. A reference standard mixture (Sigma FAME mixture 18919, Sigma-Aldrich, Deisenhofen, Germany) with additional C18:1 trans-11; C22:5n-3; conjugated linoleic acid cis-9, trans-11; C18:1 cis-11; C18:4n-3; and C22:4n-6 methyl ester was used for calibration and correction factors for individual FA.

\section{Plasma Metabolites and Leptin, and mRNA Abundance in Fat and Liver Biopsies}

Plasma metabolites (TAG, NEFA, BHBA, cholesterol, glucose) were analyzed by the Landesamt für Landwirtschaft, Lebensmittelsicherheit und Fischerei Mecklenburg-Vorpommern using routine methods. Analyses of TAG, NEFA, BHBA, cholesterol, and glucose were performed using commercially available kits (TAG: GPO-PAP, LT-TR 0015, Labor+Technik Lehmann, Berlin, Germany; NEFA: FA 115, Randox, Crumlin, UK; BHBA: RA-RB 1007, Randox; cholesterol: CHODPAP, LT-CH 0031, Labor+Technik Lehmann; glucose: GOD-PAP, LT-GL 0103, Labor+Technik Lehmann) (Hammon et al., 2008). All measurements were carried out with Cobas Mira (Roche, Basel, Switzerland).

The concentrations of plasma leptin were measured by a double antibody enzyme immunoassay as described by Sauerwein et al. (2004). The minimal detectable dose in the assay was $0.3 \mathrm{ng} / \mathrm{mL}$, and the intra- and interassay CV were 3.6 and $7.8 \%$.

Table 2. Primers used for real-time reverse transcription-PCR to analyze mRNA concentrations of leptin, leptin receptor, and acetyl-coenzyme A carboxylase $\alpha(\mathrm{ACC} \alpha), \mathrm{ACC} \alpha$ promoter $1(\mathrm{ACC} \alpha-\mathrm{P} 1)$, and $\mathrm{ACC} \alpha$ promoter $2(\mathrm{ACC} \alpha-\mathrm{P} 2)$ in s.c. fat and liver biopsy samples

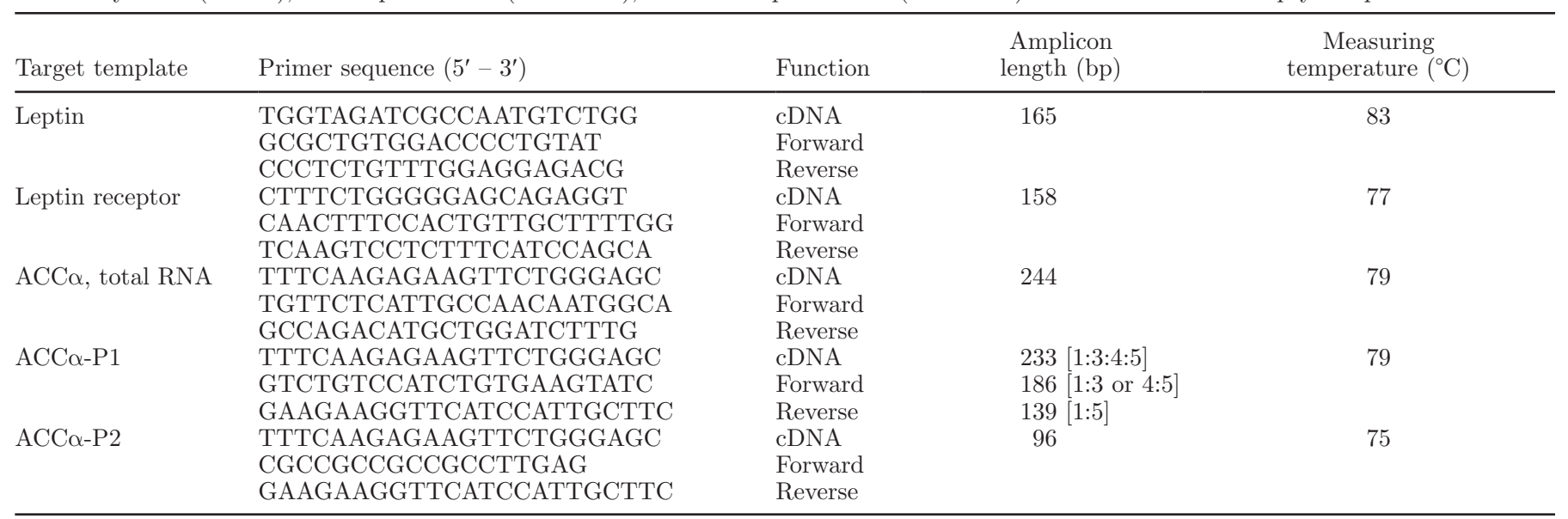


Quantification of mRNA concentrations of leptin, leptin receptor, total ACC $\alpha$, as well as the concentrations of those ACC $\alpha$ mRNA moieties derived from either promoter $1(\mathbf{A C C} \mathbf{\alpha - P} 1)$ or $2(\mathbf{A C C} \mathbf{\alpha}-\mathbf{P} 2)$ of this gene in s.c. fat and total $\mathrm{ACC} \alpha$ in liver tissue was done by real-time reverse transcription-PCR (LightCycler 2, Roche). Primer sequences are shown in Table 2. The extraction and purification of RNA and mRNA quantification with the SYBR Green I kit (Roche) was essentially as described by Goldammer et al. (2004). However, we used for each assay a cDNA equivalent derived from $75 \mathrm{ng}$ of total RNA. Relative copy numbers of the individual mRNA moieties were calculated from dilution series $\left(10^{6}\right.$ to 10 copies $)$ of the respective cDNA subclones. All samples were measured twice, from 2 independent cDNA preparations. We used gel electrophoresis to routinely validate the quality of all Light-Cycler amplicons after each run.

\section{Liver Glycogen and Fat Contents}

Freeze-dried liver biopsy samples were ground in liquid nitrogen immediately before analysis. Liver glycogen was determined using a commercial photometric test kit (Beutler, 1984) based on amyloglucosidase-catalyzed release of glucose (no. 10207748035, Boehringer Mannheim, Mannheim, Germany). Determination of liver fat content was done based on carbon and nitrogen content according to Kuhla et al. (2004). Carbon and nitrogen contents were analyzed by combustion and elemental analysis using mass spectrometry (EA 1108, Carlo Erba Instruments, Rodano, Italy; Delta S, Finnigan MAT, San Jose, CA). The content of liver fat was calculated as follows:

$$
\begin{gathered}
\text { Liver fat }(\% \mathrm{DM})=1.3038 \times \mathrm{C}(\% \mathrm{DM}) \\
-4.237 \times \mathrm{N}(\% \mathrm{DM})-0.58 \times \text { glycogen }(\% \mathrm{DM}) \\
-0.5215 \times \text { glucose }(\% \mathrm{DM}) .
\end{gathered}
$$

\section{Statistical Analyses}

All data were analyzed by ANOVA using the PROC MIXED procedure (SAS Institute, 1999) and results are presented as least squares means \pm pooled SEM. The 3 -factorial model considered the effects of diet (FD, $\mathrm{CD}$ ), the repeated factor time (week relative to calving), block $(1,2,3)$, the interaction of diet and time, and the interaction of block and diet. The DIM at the beginning of the experiment was incorporated in the model as a covariate. A post-hoc Tukey correction was performed. Measurements of DMI, EI, EB, and milk yield, obtained daily, were averaged weekly for every cow, and gene expression data was log-transformed before statistical analysis.

For analysis of plasma concentrations of TAG, NEFA, BHBA, cholesterol, glucose, and leptin as well as BW and BFT, prepartum ( $8 \mathrm{wk}$ before parturition; far-off and close-up periods), transition (3 wk before until 4 wk after parturition), postpartum [0 to $4 \mathrm{wk}, 5$ to 14 wk (95 DIM) of lactation], and the entire observation period from $55 \mathrm{~d}$ (8 wk) before parturition until 14 wk of lactation were analyzed separately. Evaluation of DMI, EI, and EB was performed for far-off dry, closeup dry, 0 to 4 wk and 5 to 14 wk postpartum, and the entire observation periods separately. The ANOVA evaluation of milk parameters using the same model as described above was conducted separately for the last $4 \mathrm{wk}$ of first lactation, and periods from 0 to $4 \mathrm{wk}$ and 5 to 14 wk of second lactation, respectively. Fatty acid composition of milk was analyzed for second lactation wk 2, 4, and 14. Hepatic fat and glycogen and s.c. fat gene expression levels were compared at $\mathrm{d}-10,1,10$, 28, and 95. Significance was defined at $P \leq 0.05$ and trends if $0.05<P<0.10$.

\section{RESULTS}

\section{$B W$ and $B F T$}

During the entire experimental period, BW and BFT were not influenced by diet (Table 3 ). Both groups increased BW during the last 8 wk of gestation. Cows of the FD and CD group lost approximately $70 \mathrm{~kg}( \pm 13.5$ $\mathrm{kg}$ ), respectively, between 1 wk before and 1 wk after parturition. The next $4 \mathrm{wk}$ were characterized by further BW losses and both groups reached a minimum BW at wk 4 of lactation with $568 \mathrm{~kg}$ in FD and $564 \mathrm{~kg}$ in $\mathrm{CD}( \pm 12.8 \mathrm{~kg})$ cows. At the end of the observation period, BW averaged 575 and $579 \mathrm{~kg} \pm 12.8$ in the FD and the CD group, respectively. Before parturition, BFT was not influenced by diet, decreased during the first $8 \mathrm{wk}$ after parturition by $0.6 \mathrm{~cm}$, and remained at $1.05 \mathrm{~cm}$ until the end of the experiment (95 DIM) irrespective of the prepartum diet.

\section{DM and El, Milk Production, and Energy Balance}

We could not find differences in DMI and milk production during the last $4 \mathrm{wk}$ of the first lactation in the 2 groups of cows (FD vs. CD: DMI, 15.4 vs. $15.2 \mathrm{~kg} / \mathrm{d}$, $P=0.86$; milk yield, 13.2 vs. $17.9 \mathrm{~kg} / \mathrm{d}, P=0.21$; fat 5.1 vs. $4.7 \%$; fat yield 672 vs. $836 \mathrm{~g} / \mathrm{d}$; protein 4.1 vs. $3.7 \%$; protein yield 566 vs. $652 \mathrm{~g} / \mathrm{d}$; all $P>0.12$ ).

Cows fed the FD diet decreased DMI during the faroff dry period, which led to a decreased EI $(P<0.05$; 
Table 3. Least squares means and pooled SEM of BW, and back fat thickness (BFT), DMI, energy intake (EI), and energy balance (EB) from far-off dry period until 95 DIM of second lactation in cows fed a diet with rumen-protected fat (FD) or a carbohydrate-based (CD) diet during the last trimester of previous gestation

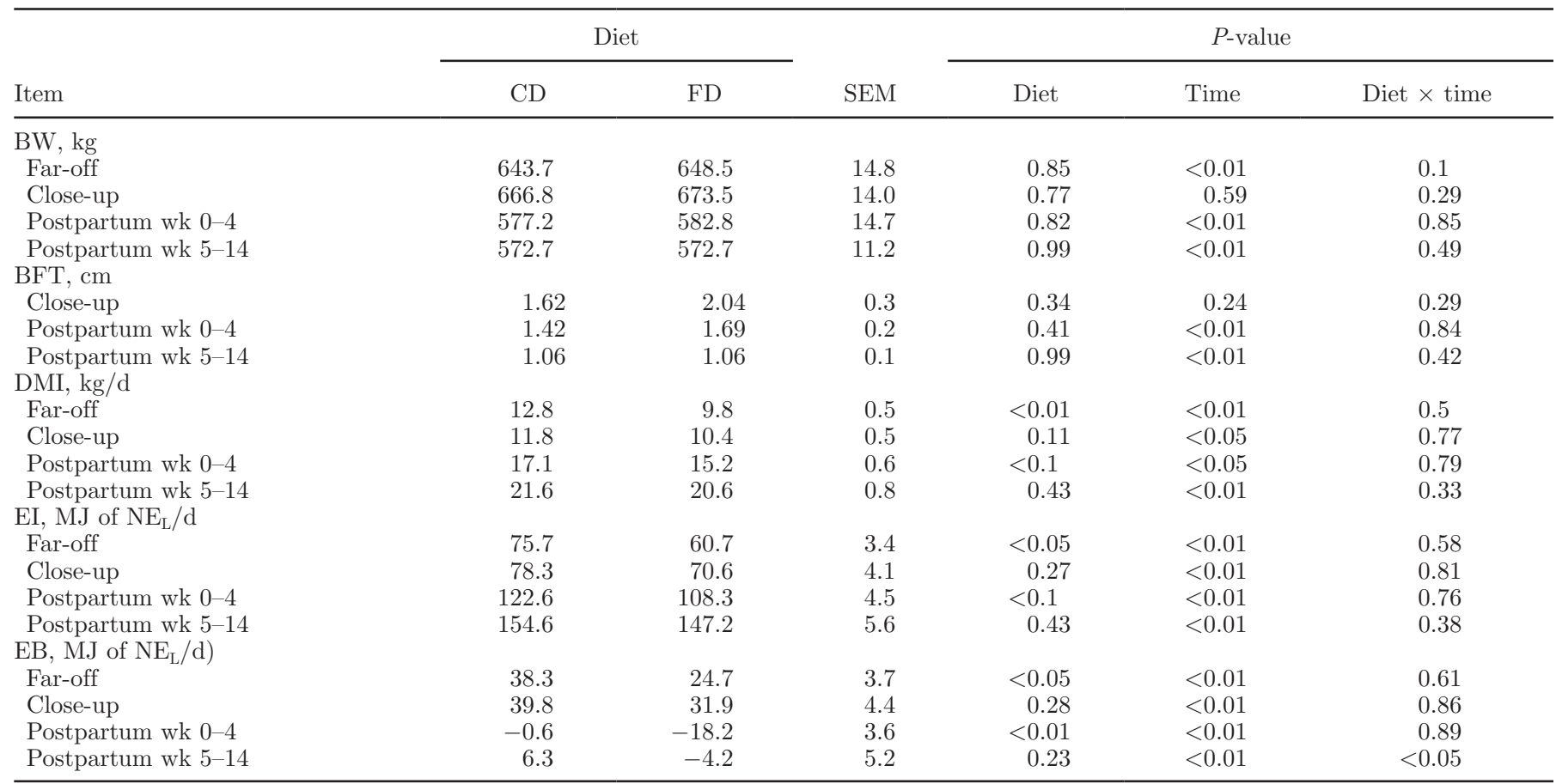

Table 3). Postpartum DMI and EI tended to be lower during the first $4 \mathrm{wk}$ of second lactation but did not differ between the FD and CD groups thereafter. In the second lactation, milk yield and ECM increased during wk 0 to 4 , and FD cows showed a lower milk yield $(P<$ 0.05 ), but not ECM, whereas during wk 5 to 14 , milk yield and ECM decreased, but did not differ between groups $(P=0.3$; Figure $1 \mathrm{~A}$ and $\mathrm{B})$. The percentage of milk fat and protein was affected by prepartum feeding. Fat content in milk was higher $(P<0.1$ and $P<0.05)$ and protein content tended to be higher $(P<0.1)$ from wk 5 in cows fed the diet with rumen-protected fat prepartum (Table 4). Milk lactose content and lactose yield were decreased for cows of the FD group during lactation wk 0 to $4(P<0.05)$.

All cows were in positive EB prepartum and in negative EB postcalving until wk 11 and 8 for the FD and CD groups, respectively $(P=0.7)$. Cows of the FD group had a less positive EB during the far-off dry period $(P<0.05$; Table 3$)$ and showed a more negative EB balance during the first $4 \mathrm{wk}$ postpartum $(P<$ $0.01)$.

No diet-dependent differences were observed for milk FA composition (data not shown) with the exception of C14:0 and C16:1. The FD group had a higher proportion of C16:1 (2.7 vs. 2.1\%) and lower contents of C14:0 (11.2 vs. $12.5 \%)$ at all time points measured $(P$ $<0.05)$.

\section{Plasma Concentrations of TAG, NEFA, BHBA, Cholesterol, and Glucose}

Plasma TAG concentrations prepartum were higher in cows fed FD $(P<0.01$; Figure $2 \mathrm{~A})$. Considering the transition period between 3 wk before to 4 wk after parturition, TAG concentrations in FD were higher in contrast to $\mathrm{CD}(P<0.01)$. With the onset of lactation, TAG concentrations decreased in both groups but remained higher for $10 \mathrm{~d}$ in the FD group $(P<$ 0.05). Prepartum plasma concentrations of NEFA were higher in FD $(P<0.05)$ than in $\mathrm{CD}$ cows but did not differ postpartum between the feeding groups (Figure 2B). Plasma NEFA concentrations began to increase distinctly around $7 \mathrm{~d}$ before parturition and peaked immediately after parturition. Plasma BHBA concentrations were lower in FD prepartum $(P<0.05)$, whereas no diet-related differences were observed throughout the postpartum period (Figure 2C). Circulating BHBA concentrations decreased from 8 to 1 wk before calving and increased with the onset of lactation in both groups to reach a maximum at 5 DIM for cows fed FD and at 10 DIM for cows fed CD $(P=0.9)$ before returning to prepartum concentrations. Plasma cholesterol concentration was higher $(P<0.05)$ during the prepartum period in the FD group but decreased particularly during the last $3 \mathrm{wk}$ before parturition (Figure 2D). After calving, the differences were reduced but 
Table 4. Least squares means and pooled SEM of second lactation milk composition during lactation wk 0 to 4 and 5 to 14 of cows fed a diet with rumen-protected fat (FD) or a carbohydrate-based (CD) diet during the last trimester of previous gestation

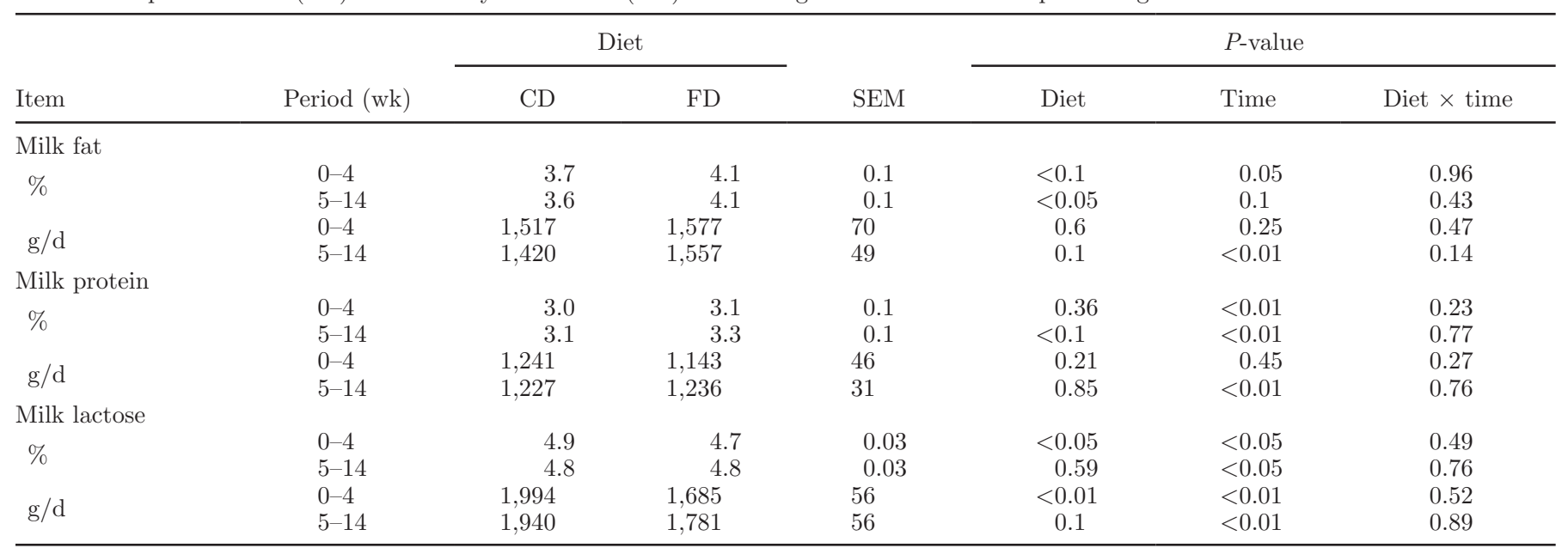

plasma cholesterol remained higher in FD cows during the transition and postpartum period $(P<0.05)$. In cows supplemented with fat prepartum, plasma glucose concentrations were lower between $-30 \mathrm{~d}$ until parturition $(P<0.05)$ and remained lower postpartum until the end of the observation period as compared with $\mathrm{CD}$ $(P<0.05$; Figure 3$)$.

\section{Plasma Concentrations of Leptin and mRNA Abundance in Fat and Liver Biopsies}

Plasma leptin concentration increased slightly until parturition irrespective of the diet, then declined rapidly to reach a nadir at $10 \mathrm{~d}$ after parturition, and remained low until the end of the observation period (Figure 4A). Concomitantly, leptin mRNA concentration in s.c. fat declined from $10 \mathrm{~d}$ before parturition to $10 \mathrm{~d}$ after, then remained constant (Figure 4B) but did not differ among feeding groups. Copy numbers of leptin receptor mRNA in the FD group followed the same pattern as leptin mRNA, whereas in CD cows, it remained on a similar level pre- and postpartum, but prepartum diet was not a significant factor (Figure 4C). Total ACC $\alpha$ as well as ACC $\alpha-\mathrm{P} 1$ mRNA abundance in s.c. fat decreased from $10 \mathrm{~d}$ before parturition to $1 \mathrm{~d}$ after by $97 \%$ and remained on a low level until 95 DIM irrespective of the diet (Figure 5A, B). The ACC $\alpha-\mathrm{P} 2$ mRNA concentration was at a much lower level than ACC $\alpha-\mathrm{P} 1 \mathrm{mRNA}$ and declined peripartum by only $50 \%$, hence a less drastic reduction as compared with total $\mathrm{ACC} \alpha$ and $\mathrm{ACC} \alpha-\mathrm{P} 1 \mathrm{mRNA}$ (Figure $5 \mathrm{C}$ ). Liver tissue total ACC $\alpha$ (Figure 5D), ACC $\alpha-P 1$, and ACC $\alpha-P 2$ (data not shown) mRNA abundance were generally at a lower level than in s.c. fat and remained unchanged from pre- to postpartum but increased slightly from
1 to 95 d postpartum. Prepartum diet was not a significant factor here. Ten days prepartum, total ACC $\alpha$ mRNA abundance in s.c. fat was 15 times higher than in liver. At 95 DIM, total ACC $\alpha$ mRNA concentrations were equivalent in s.c. fat and liver.

\section{Liver Fat and Glycogen Contents}

Content of liver fat increased between $10 \mathrm{~d}$ before calving to reach a maximum at $+10 \mathrm{~d}$ postpartum and decreased thereafter (Figure $6 \mathrm{~A}$ ). Although ANOVA did not show a significant effect of the prepartum diet, liver fat values of the FD group were numerically higher before parturition and did not show changes as distinct as those observed in the CD group. Liver glycogen followed an inverse course with minimum values at $10 \mathrm{~d}$ postpartum (Figure 6B). We could not find differences between feeding groups due to the large variation of liver fat values, which demands that these data be interpreted with caution. Nevertheless, liver fat-to-glycogen ratio prepartum was about 5 times as high in FD than in $\mathrm{CD}$ cows $(4.8$ vs. $1.0 ; P<0.01)$.

\section{DISCUSSION}

We expected that higher dietary fat intake prepartum could prevent excessive lipid mobilization in adipose tissue and thereby ameliorate DMI and EB in the subsequent lactation. However, fat feeding $12 \mathrm{wk}$ prepartum in first-lactating cows resulted in reduced DMI prepartum, reduced milk yield in the first $4 \mathrm{wk}$ of lactation, and a more negative EB. This was accompanied by increased milk fat and reduced lactose percentage, whereas protein percentage tended to be lower from wk 5 on. Daily lactose output was reduced 

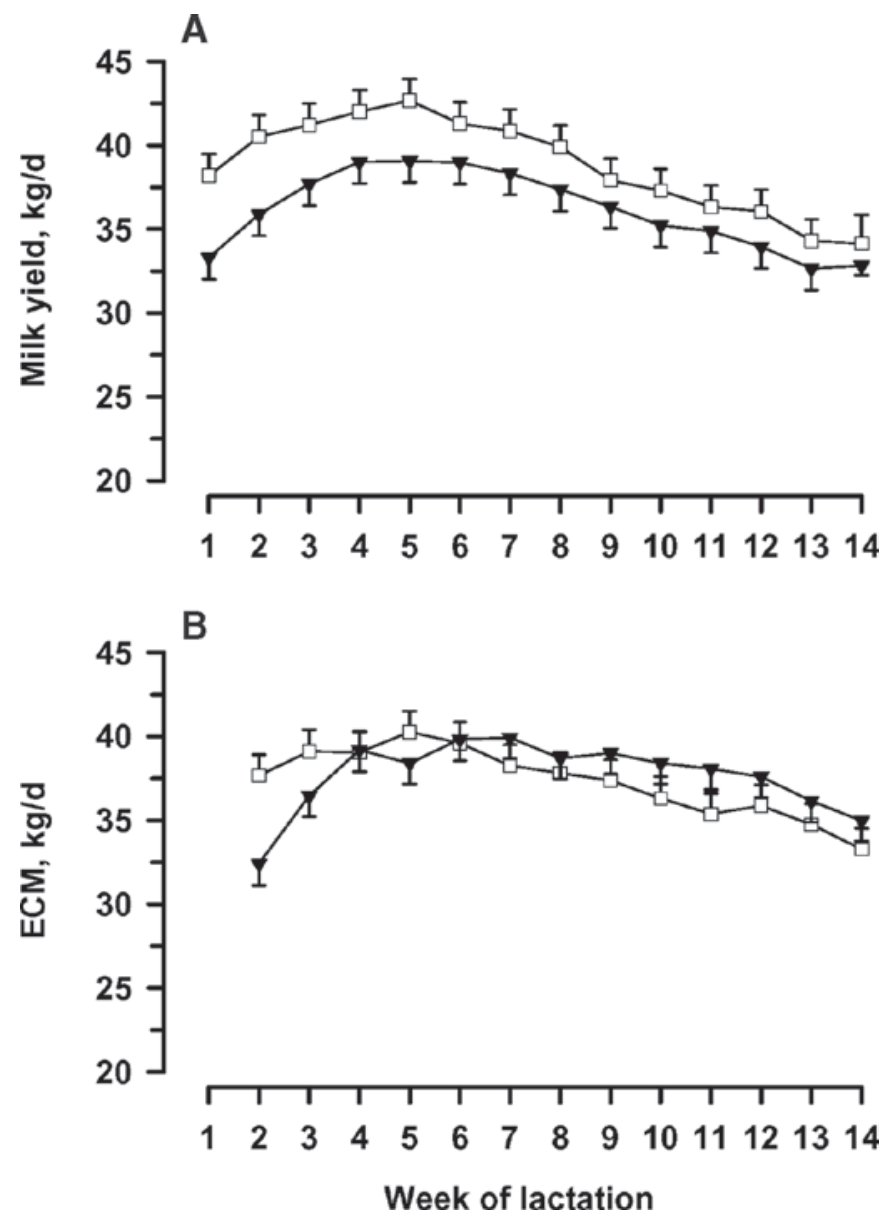

Figure 1. Least squares means of second lactation milk yield (A) and ECM yield (B) of cows fed a diet with rumen-protected fat ( $\mathbf{\nabla})$ or control diet $(\square)$ during the last trimester of previous gestation.

as a function of milk volume. Milk energy output was equivalent between feeding groups. Although not reaching statistical significance, in FD, we observe higher milk fat and protein percentage during the last $4 \mathrm{wk}$ of first lactation. The reason for this is not apparent, but we suspect that higher milk fat percentage during this period is due to TAG transported by chylomicrons and utilized by the mammary gland. However, the small number of cows per treatment and the large variation demand that these data be interpreted with caution.

It is somewhat surprising that the FD group showed a more negative EB during early lactation in spite of unchanged ECM values and no difference in body fatness as judged by BFT and liver fat content. This might presumably be due to the numerically reduced EI postpartum (wk 0 to 4 ), which might be related to lower EI prepartum caused by prepartum fat feeding. In fact, when comparing DMI and EI for the whole period from the start of the experimental feeding to 95 DIM, both were lower for the FD group (DMI: 15.7 vs. 17.5 $\mathrm{kg} / \mathrm{d}, P=0.05 ; \mathrm{EI}: 110$ vs. $120.4 \mathrm{MJ}$ of $\mathrm{NE}_{\mathrm{L}} / \mathrm{d}, P=$ $0.08)$. It has been previously observed that prepartum fat feeding reduces postpartum feed intake (Moallem et al., 2007b).

Generally, studies addressing effects of prepartum fat feeding differ in regard to timing and duration of fat supplementation, energy density of the rations, and FA composition of the dietary fat. In only a few studies, fat-containing diets were fed solely during the dry period for 21, 35, 40, and $60 \mathrm{~d}$ before calving (Douglas et al., 2004, 2007; Moallem et al., 2007b; Andersen et al., 2008), whereas in the study of Grum et al. (1996), fat was administered between 60 and $7 \mathrm{~d}$ before calving. The present study differs from these because the fat diet was fed during the last 4 wk of first lactation and the whole dry period $(84 \mathrm{~d})$. Examination of the effect of dietary energy density in studies with fat feeding prepartum on DMI and milk production yields contradictory results. When energy density was similar to that of the control group, DMI and EI were reduced prepartum (Moallem et al., 2007a; Petit et al., 2007) and postpartum (Moallem et al., 2007b), which agrees with the present findings, or unaltered pre- and postpartum (Douglas et al., 2004; Andersen et al., 2008). In line with EI, milk yield in the subsequent lactation was reduced (Moallem et al., 2007b) or unchanged (Douglas et al., 2004; Andersen et al., 2008). When energy density was higher due to fat supplementation, DMI and EI were lower but milk yield did not differ from control values (Grum et al., 1996), or DMI was unchanged but EI was higher (Skaar et al., 1989). In FD, milk yield and EB were reduced after prepartum fat feeding, which is in line with findings of Moallem et al. (2007b) but disagrees with other studies (Grum et al., 1996; Douglas et al., 2004; Andersen et al., 2008).

It has been shown that especially unsaturated FA depress DMI intake with negative effects on milk yield (Bremmer et al., 1998; Harvatine and Allen, 2006; Douglas et al., 2007; Moallem et al., 2007b), which was not found in the study of Anderson et al. (2008). Unsaturated FA in the dietary fat used in our study accounted for $\sim 50 \%$ of total FA. Taking into account that during the dry period FD cows were provided with about 280 to $480 \mathrm{~g}$ of rumen-protected fat per day, which corresponded to 135 and $238 \mathrm{~g}$ of unsaturated long-chain FA (LCFA) per day during far-off and close-up periods, respectively, this is comparable to unsaturated LCFA intakes in other studies reporting reduced DMI (Douglas et al., 2007; Moallem et al., 2007a). Allen (2000) reported that fat supplements consisting of Ca salts of palm oil, similar to the fat used in our study, reduce DMI in about $50 \%$ of the studies. In this context, it is noteworthy that FD cows showed increased prepartum plasma NEFA concentrations, which might be a caus- 

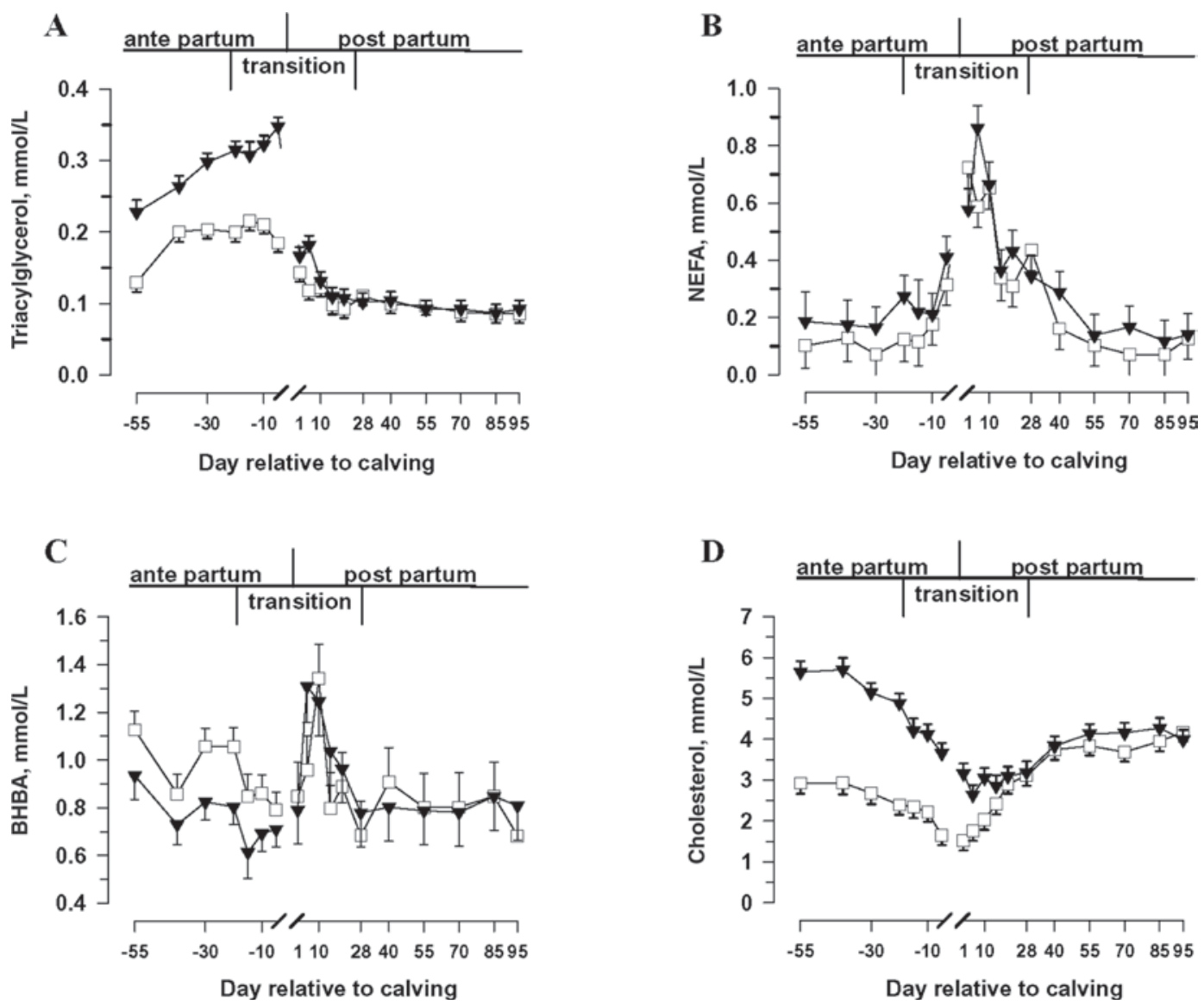

Figure 2. Least squares means of pre- and postpartum plasma concentrations of triacylglycerol (A), NEFA (B), BHBA (C), and cholesterol (D) of cows fed a diet with rumen-protected fat $(\mathbf{\nabla})$ or control diet $(\square)$ during the last trimester of gestation.

ative factor for the observed lower DMI during this period (Ingvartsen and Andersen, 2000; Allen et al., 2005). It was shown that LCFA also in ruminants act as signals of satiety and energy status to the brain mediated in part via increased secretion of cholecystokinin and glucagon-like peptide-1 (Bradford et al., 2008).

The reasons for the effects on EI and milk yield in the FD cows during subsequent lactation are unknown but might be related to the long duration of prepartum fat feeding (i.e., the last trimester of pregnancy). Because prepartum diets were targeted to be isoenergetic, it might be that the lower DMI and EI during the far-off period were causatively related to the higher prepartum plasma NEFA concentrations in FD. Lower plasma glucose levels in fat-fed cows throughout the observation period could have been limiting mammary glucose supply and thus lactose production. Another potential explanation might be related to differences in remodeling of mammary epithelial cells of the 2 groups of cows in late pregnancy. Growth hormone and IGF-1 and IGF binding proteins are involved in mammary gland involution during which senescent mammary epi- thelial cells are replaced with newly established cells by apoptosis and proliferation (Baumrucker and Erondu, 2000; Accorsi et al., 2002). Plasma IGF-1 is a function of EI, decreases prepartum, and is inversely related with NEFA concentration (Vandehaar et al., 1999; Radcliff et al., 2003). Thus, although we have not measured IGF systems in the present study, we speculate that in FD cows due to lower EI during the far-off period or specific effects of prepartum dietary fat, the number of renewed mammary secretory cells may be lower, leading to a reduced capacity for milk production in the next lactation.

Evaluation of the metabolic variables recorded prepartum revealed higher plasma TAG in the FD group until $10 \mathrm{~d}$ postpartum, which mirrors the acute effect of fat feeding and is consistent with increased LCFA small intestinal absorption (Palmquist and Conrad, 1978; Lough et al., 1988). Upon calving, supplemental dietary fat intake ceased but plasma TAG remained higher than in the CD group for $10 \mathrm{~d}$. Plasma lipoproteins carrying large amounts of TAG are chylomicrons during the postprandial state and VLDL secreted by 


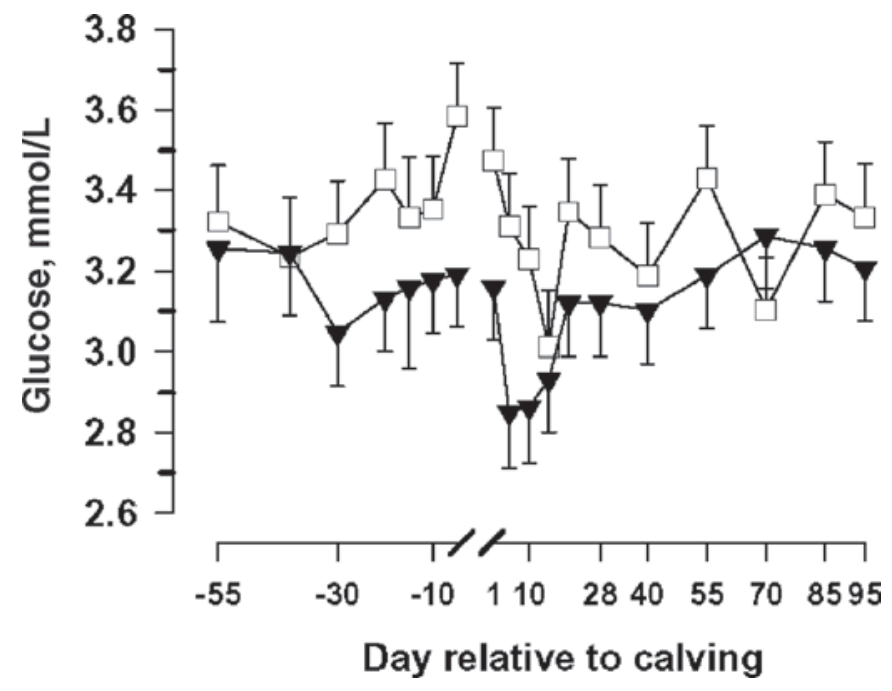

Figure 3. Least squares means of pre- and postpartum plasma glucose concentrations of cows fed a diet with rumen-protected fat $(\mathbf{\nabla})$ or control diet $(\square)$ during the last trimester of gestation.

the liver. Thus, although plasma TAG prepartum are probably due to chylomicrons, the transient persistence of increased plasma TAG may indicate an increased secretion of hepatic TAG via VLDL. However, ruminant animals have a known low rate of VLDL secretion (Kleppe et al., 1988) and a high VLDL turnover rate, which makes increased VLDL an unlikely explanation.

Higher plasma cholesterol values prepartum in FD cows confirm earlier results in dairy cows intragastrically infused or fed with supplemental fat (Bremmer et al., 1998; Douglas et al., 2007; Andersen et al., 2008). As shown for ruminants and monogastric animals, this is presumably caused by increased intestinal and hepatic cholesterol synthesis because the fat used in this study did not contain cholesterol (Coleman et al., 1960; Nestel et al., 1978; Grummer and Carroll, 1988). Higher plasma cholesterol values in FD cows persisted postpartum, which is in line with results of Douglas et al. (2007). Because lactation diet contained the same fat source for all cows, which was free of cholesterol, increased plasma cholesterol values might be due to highdensity lipoproteins, as well as low-density lipoproteins and lipoprotein remnant particles derived from VLDL metabolism (Grummer and Carroll, 1988). Bernabucci et al. (2004) reported higher plasma cholesterol levels after parturition and increases of apolipoprotein $\mathrm{E}$ and plasma high-density lipoprotein percentage from preto postcalving, whereas hepatic apolipoprotein $\mathrm{B}_{100}$ and plasma VLDL percentage decrease. This might suggest alterations of posthepatic lipoprotein metabolism in cows fed fat prepartum.

Indicators of body fat mobilization and ketogenesis, such as BFT, plasma NEFA, and BHBA, exhibited no
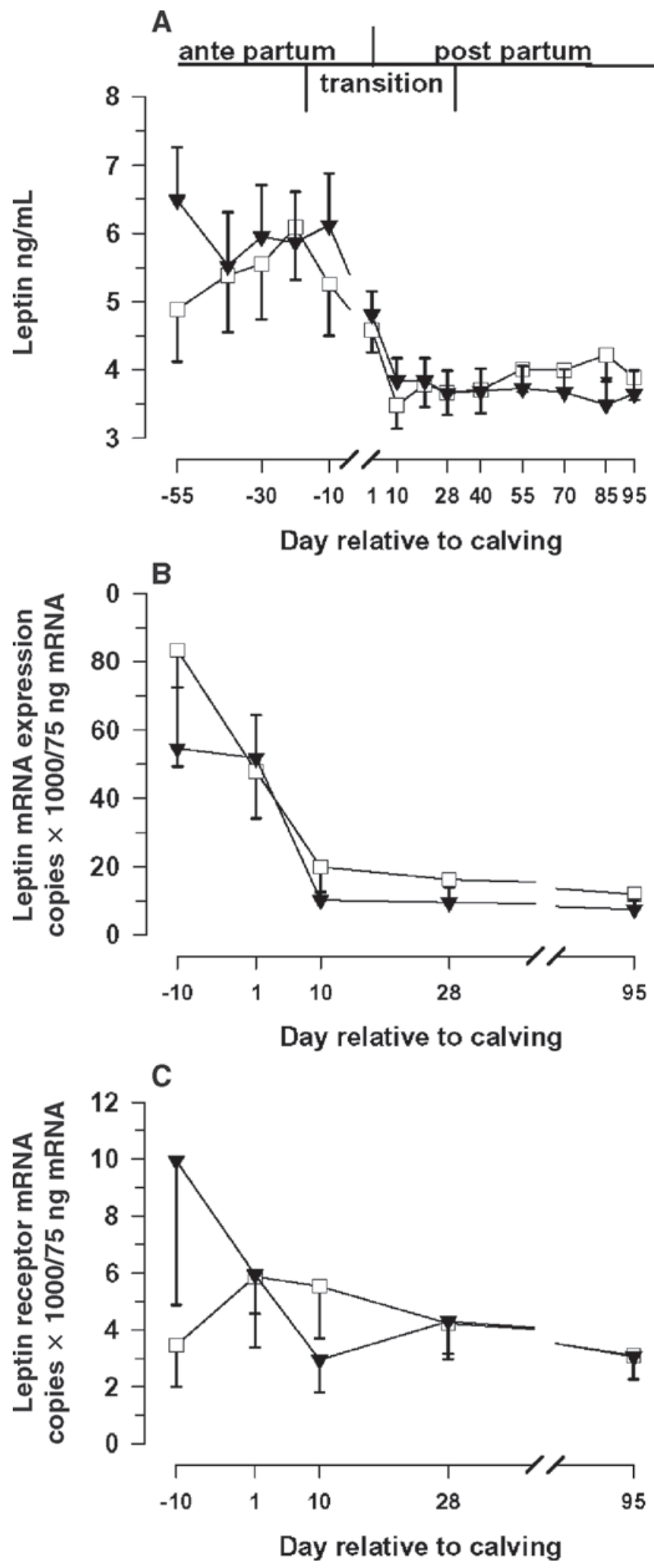

Figure 4. Least squares means of pre- and postpartum plasma leptin concentration (A) and mRNA expression of leptin (B) and leptin receptor (C) in s.c. fat of cows fed a diet with rumen-protected fat $(\boldsymbol{\nabla})$ or control diet $(\square)$ during the last trimester of gestation. 

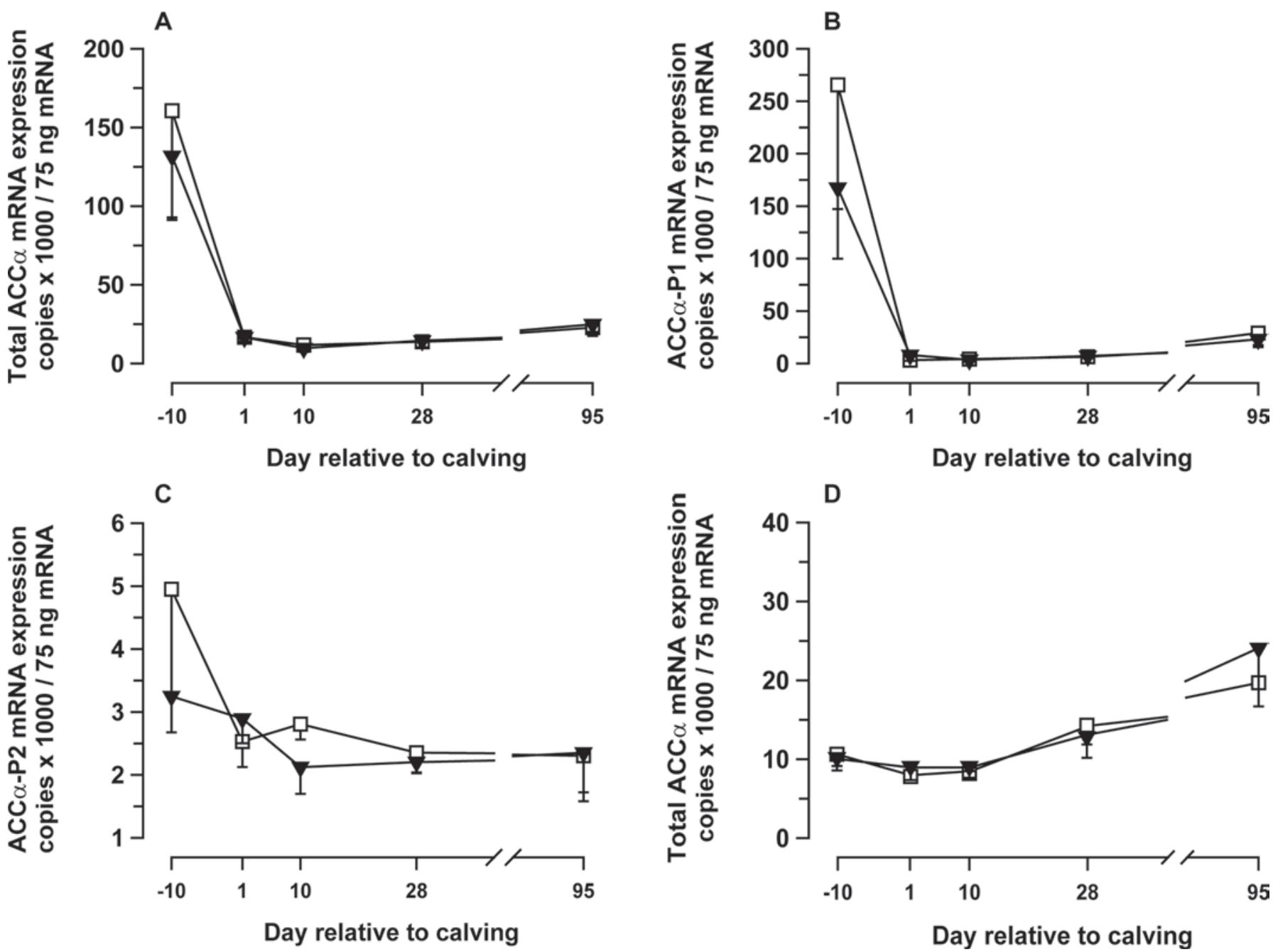

Figure 5. Least squares means of pre- and postpartum mRNA expression of total acetyl-coenzyme A carboxylase $\alpha$ (ACC $\alpha$; A), ACC $\alpha$ promoter 1 (ACC $\alpha-\mathrm{P} 1 ; \mathrm{B}), \mathrm{ACC} \alpha$ promoter $2(\mathrm{ACC} \alpha-\mathrm{P} 2$; $\mathrm{C})$ in s.c. fat and total $\mathrm{ACC} \alpha$ in liver tissue (D) of cows fed a diet with rumen-protected fat $(\boldsymbol{\nabla})$ or control diet $(\square)$ during the last trimester of previous gestation. Note different scaling of y-axis in the panels.

diet-dependent difference during the postpartal period. However, before parturition, plasma NEFA concentrations were higher, and plasma BHBA concentrations were lower in the FD group. That plasma NEFA concentration prepartum is increased with fat feeding has been reported previously (Skaar et al., 1989; Grum et al., 1996; Douglas et al., 2007; Andersen et al., 2008). This is likely due to an increased activity of lipoprotein lipase, which released LCFA from chylomicron-derived TAG without increased disposal of LCFA in peripheral tissues. In periparturient cows, it was shown that the increase of plasma NEFA as a reflection of body fat mobilization and insufficient FA oxidation is associated with hepatic lipid accumulation (Vazquez-Añon et al., 1994), and 1 study reported elevated liver lipids at parturition in cows fed high-fat diets for 19 wk during the previous mid to late lactation (Vazquez-Añon et al., 1997). We found a numerically increased hepatic lipid accumulation (17 vs. 8\%) and a higher liver fat-toglycogen ratio prepartum in FD as compared with CD cows but not postpartum. No difference of hepatic lipid content as compared with control values before parturition was found by Grum et al. (1996) and Andersen et al. (2008) when feeding fat prepartum. However, Grum et al. (1996) reported lower liver lipid concentrations postpartum when fat was supplied prepartum, whereas this was only found with saturated fat by Anderson et al. (2008). Interestingly, Andersen et al. (2008) did not observe increased hepatic LCFA oxidation in spite of reduced liver TAG content when polyunsaturated LCFA were fed but found indications for increased hepatic generation of acetyl-coenzyme A (ketogenesis) in the fat-supplemented group prepartum. In contrast, others did not observe differences in liver lipid con- 

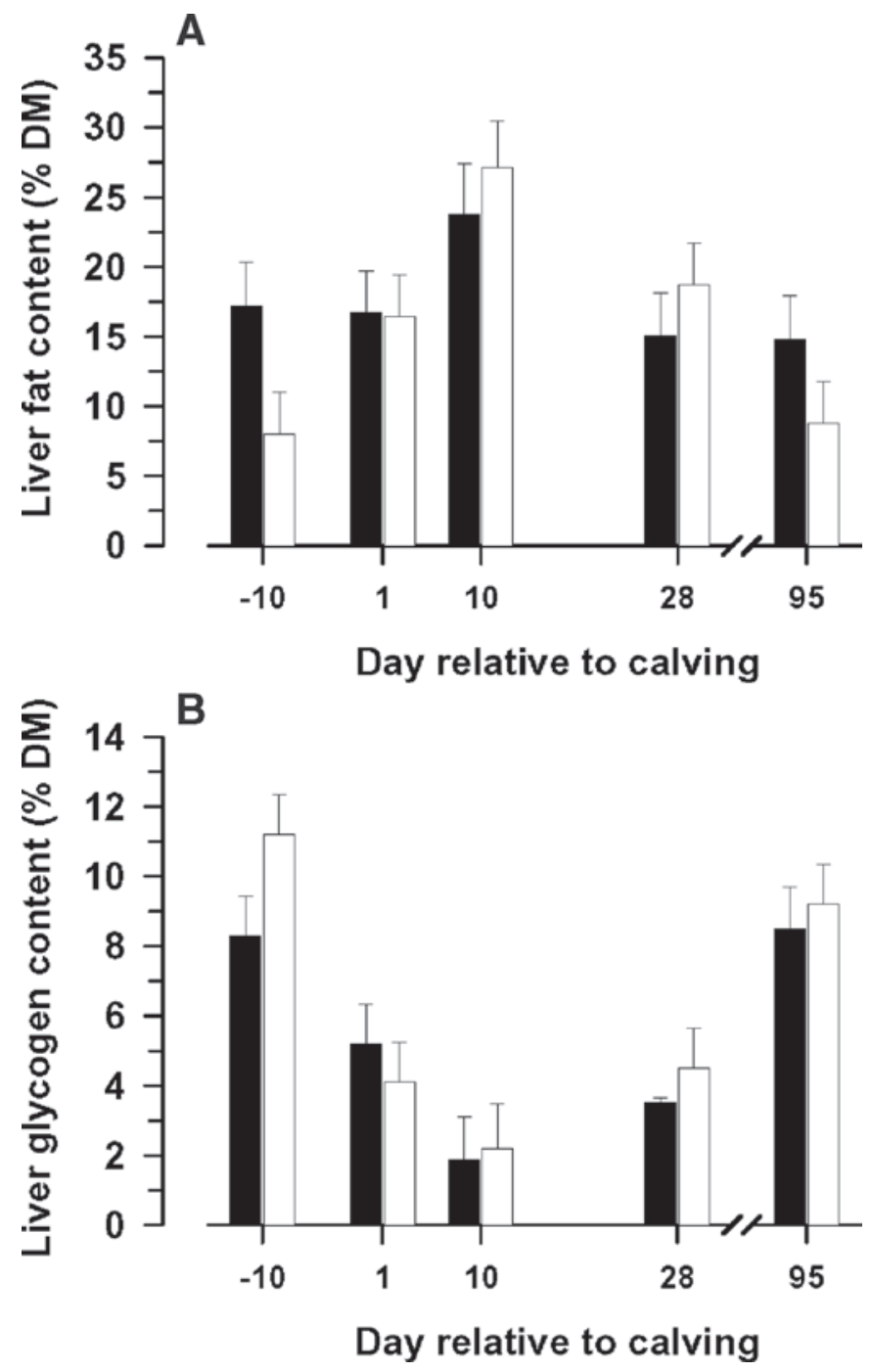

Figure 6. Least squares means of pre- and postpartum liver fat (A) and liver glycogen content (B) of cows fed a diet with rumen-protected fat (filled columns) or control diet (open columns) during the last trimester of gestation.

centration due to prepartum fat and suggested that a lower nutrient intake prepartum could explain the findings of Grum et al. (1996) (Douglas et al., 2004). Thus, our observations confirm those of others (Douglas et al., 2004, 2007) and are in contrast to the proposition that a high-fat diet prepartum could adapt the liver for oxidative LCFA disposal and decreased hepatic lipid accumulation (Grum et al., 1996; Andersen et al., 2008). However, due to the high variability of liver fat in our study, this conclusion should be considered with caution.

That fat feeding prepartum does not increase BHBA concentrations prepartum has been shown before (Grum et al., 1996; Douglas et al., 2004, 2006) and is likely an effect of the reduced carbohydrate supply as compared with the CD control group, which might have caused higher concentrations of ruminal butyrate, which is converted to BHBA in the rumen wall (Sutton, 1985).

Hepatic gluconeogenesis can be negatively affected by LCFA (Mashek and Grummer, 2003). Thus, the observed reduced plasma glucose concentrations prepartum may be due to a reduced gluconeogenesis rate or a reduced carbohydrate supply, or both. Whether a possibly impaired hepatic gluconeogenesis rate persists and can thus explain the reduced plasma glucose concentrations postpartum is subject to further investigation. However, we recently found no difference in glucose production but lower plasma glucose in dairy cows fed the same rumen-protected fat as in the present study (Hammon et al., 2008). Another explanation might be that glucose was used for milk fat synthesis.

Leptin is a signal from energy stores to the hypothalamus and is involved in food-intake regulation and energy homeostasis. Leptin is mainly produced in white adipose tissue and thus reflects body fatness (Chilliard et al., 2005). In line with the course of BFT, plasma leptin exhibited no diet-dependent difference but declined from pre- to postpartum, which is in accordance with recent reports (Holtenius et al., 2003; Reist et al., 2003; Hachenberg et al., 2007). Feeding of oil or palm oil Ca salts in early, mid, or late lactating cows or from $20 \mathrm{~d}$ before until $75 \mathrm{~d}$ postpartum did not alter plasma leptinemia, which is in accordance with the results of the present study (Chilliard et al., 2005; Becu-Villalobos et al., 2007). Plasma leptin seems to be directly associated with dietary energy level (Holtenius et al., 2003; Reist et al., 2003). Because there was no dramatic difference in EI in our study, plasma leptin was not affected by the prepartum diet. The decreases in leptinemia and leptin mRNA abundance in early lactation were in accordance with the beginning fat mobilization during transition and with the course of BFT decrease. The results appear to exclude an effect of macronutrient composition prepartum on leptin receptor mRNA in s.c. fat.

The rate-limiting enzyme of FA synthesis, ACC $\alpha$, was shown to be downregulated by restricted EI and upregulated by the supply of glucogenic substrates in s.c. fat of sheep (Moibi et al., 2000; Lee and Hossner, 2002). Thus, one would expect higher transcript levels in the CD group, which were not seen in periparturient cows of this study. Transcript levels of ACC $\alpha$ and those derived from the most relevant promoter, $\mathrm{ACC} \alpha-\mathrm{P} 1$, in s.c. fat decreased dramatically from $-10 \mathrm{~d}$ until $+1 \mathrm{~d}$ relative to parturition. The abundance of transcripts derived from $\mathrm{ACC} \alpha-\mathrm{P} 2$ also decreased peripartum but to a much lesser extent. The data show for the cow that in adipose tissue, $\mathrm{ACC} \alpha-\mathrm{P} 1$ activity is regulated to a much larger extent than the activity of $\mathrm{ACC} \alpha-\mathrm{P} 2$. This is in line with previous claims that $\mathrm{ACC} \alpha-\mathrm{P} 1$ would 
be the nutritionally regulated promoter and ACC $\alpha-\mathrm{P} 2$ representing the housekeeping promoter (Mao et al., 2001; Mao and Seyfert, 2002). However, because the activity of $\mathrm{ACC} \alpha-\mathrm{P} 2$ is also reduced, it is clear that the metabolic reprogramming peripartum reduces the activity of both ACC $\alpha$ promoters in adipose tissue of the cow. These findings are in line with previous reports from rats and cows that ACC $\alpha$ mRNA abundance in adipose tissue decreases dramatically from pre- to postpartum (Ponce-Castaneda et al., 1991; Doepel et al., 2002; Sumner et al., 2008), indicating that FA synthesis in s.c. fat is shut off immediately at parturition irrespective of dietary nutrient composition. It is known from cattle that the major site for FA synthesis is adipose tissue, and not liver. We find that the total $\mathrm{ACC} \alpha$ mRNA concentration in the liver is low as expected and largely unaffected by the metabolic changes during the transition phase but increases between 10 and $95 \mathrm{~d}$ postpartum. Although we have not measured mammary gland $\mathrm{ACC} \alpha$, our finding that milk fat in the FD group had a lower content of C14:0 FA at all time points measured suggests a lower FA synthesis. Almost all milk C4:0 to C14:0 FA are derived from de novo synthesis in mammary epithelial cells, and it has been shown that fat supplementation during established lactation reduces medium-chain FA in milk fat (DePeters et al., 1989; Beaulieu and Palmquist, 1995). Because in the FD group milk fat percentage was higher, this suggests that less milk FA originate from de novo synthesis but rather stem from body fat, which would agree with the higher levels of C16:1 in milk fat observed in that group.

\section{CONCLUSIONS}

Our present findings indicate that prepartum supplementation with $\mathrm{Ca}$ salts of palmitic and oleic acids in dairy cows results in EI depression prepartum, which was associated with reduced milk yield, a depressed EI, and a reduced EB during the first 4 wk of subsequent lactation. The data provide no indications for changes in regard to lipid mobilization postpartum and liver lipid accumulation. However, the relatively small number of cows per treatment and the large variation of liver fat values demand that these data be interpreted with caution. We speculate that lower EI during the far-off period or specific effects of prepartum fat may have lowered the number of renewed mammary secretory cells, leading to a reduced capacity for milk production in the next lactation. It cannot be excluded that EI affected lactation variables to a similar degree than prepartum fat feeding. Metabolic effects of fat feeding prepartum largely agree with earlier reports with the exception that increased plasma TAG and cholesterol and decreased plasma glucose persist during early lactation. In line with previous reports, the activity of total ACC $\alpha$ and both ACC $\alpha$ promoters in adipose tissue is dramatically reduced from pre- to postpartum. The results appear to exclude an effect of macronutrient composition prepartum on leptin, leptin receptor, total $\mathrm{ACC} \alpha$, and $\mathrm{ACC} \alpha$ promoter transcript levels in s.c. fat during transition. In conclusion, feeding a diet containing rumen-protected fat for 12 wk during late lactation and dry period until calving negatively affected DMI, $\mathrm{EB}$, and milk yield during subsequent lactation and was not beneficial in regard to liver lipid accumulation.

\section{ACKNOWLEDGMENTS}

We thank the technical staff of the Research Institute for the Biology of Farm Animals (FBN) research units "Nutritional Physiology" and "Molecular Biology" as well as to Gunter Klautschek and the animal care takers of the FBN for excellent technical assistance. The Rinderzuchtverband Mecklenburg-Vorpommern is acknowledged for logistic support with selection of cows. The study was supported by a grant of the Deutsche Forschungsgemeinschaft, Bonn, Germany, to H. M. S. and C. C. M. (SE 326/13-2), and the core budget of the FBN.

\section{REFERENCES}

Accorsi, P. A., B. Pacioni, C. Pezzi, M. Forni, D. J. Flint, and E. Seren. 2002. Role of prolactin, growth hormone and insulin-like growth factor 1 in mammary gland involution in the dairy cow. J. Dairy Sci. 85:507-513.

Ainslie, D. A., J. Proietto, B. C. Fam, and A. W. Thorburn. 2000. Short-term, high-fat diets lower circulating leptin concentrations in rats. Am. J. Clin. Nutr. 71:438-442.

Allen, M. S. 2000. Effects of diet on short-term regulation of feed intake by lactating dairy cattle. J. Dairy Sci. 83:1598-1624.

Allen, M. S., B. J. Bradford, and K. J. Harvatine. 2005. The cow as a model to study food intake regulation. Annu. Rev. Nutr. 25:523-547.

Andersen, J. B., C. Ridder, and T. Larsen. 2008. Priming the cow for mobilization in the periparturient period: Effects of supplementing the dry cow with saturated fat or linseed. J. Dairy Sci. 91:10291043.

Baumrucker, C. R., and N. E. Erondu. 2000. Insulin-like growth factor system in the bovine mammary gland and milk. J. Mammary Gland Biol. Neoplasia 5:53-64.

Beaulieu, A. D., and D. L. Palmquist. 1995. Differential effects of high fat diets on fatty acid composition in milk of Jersey and Holstein cows. J. Dairy Sci. 78:1336-1344.

Becu-Villalobos, D., I. Garcia-Tornadu, G. Shroeder, E. E. Salado, G. Gagliostro, C. C. Delavaud, Y. Chilliard, and I. M. LacauMengido. 2007. Effect of fat supplementation on leptin, insulin-like growth factor 1 , growth hormone, and insulin in cattle. Can. J. Vet. Res. 71:218-225.

Bell, A. W. 1995. Regulation of organic nutrient metabolism during transition from late pregnancy to early lactation. J. Anim. Sci. $73: 2804-2819$.

Bernabucci, U., L. Basirico, N. Lacetera, P. Morera, B. Ronchi, P. A. Accorsi, E. Seren, and A. Tardone. 2006. Photoperiod affects gene expression of leptin and leptin receptors in adipose tissue from lactating dairy cows. J. Dairy Sci. 89:4678-4686. 
Bernabucci, U., B. Ronchi, L. Basirico, D. Piazzi, F. Rueca, N. Lacetera, and A. Tardone. 2004. Abundance of mRNA of apolipoprotein $B_{100}$, apolipoprotein $\mathrm{E}$, and microsomal triglyceride transfer protein in liver from periparturient dairy cows. J. Dairy Sci. 87:2881-2888.

Beutler, H. O. 1984. Pages 2-10 in Methods of Enzymatic Analysis. 3rd. ed. Vol. VI. H. U. Bergmeyer, ed.Verlag Chemie, Weinheim, Germany.

Bradford, B. J., K. J. Harvatine, and M. S. Allen. 2008. Dietary unsaturated fatty acids increase plasma glucagon-like peptide-1 and cholecystokinin and may decrease premeal ghrelin in lactating dairy cows. J. Dairy Sci. 91:1443-1450.

Bremmer, D. R., L. D. Ruppert, J. H. Clark, and J. K. Drackley. 1998. Effects of chain length and unsaturation of fatty acid mixtures infused into the abomasums of lactating dairy cows. J. Dairy Sci. 81:176-188.

Cha, M. C., and P. J. H. Jones. 1998. Dietary type and energy restriction interactively influence plasma leptin concentration in rats. J. Lipid Res. 39:1655-1660.

Chelikani, P. K., D. R. Glimm, and J. J. Kennelly. 2003. Short communication: Tissue distribution of leptin and leptin receptor mRNA in the bovine. J. Dairy Sci. 86:2369-2372.

Chilliard, Y., C. Delavaud, and M. Bonnet. 2005. Leptin expression in ruminants: Nutritional and physiological regulations in relation with energy metabolism. Domest. Anim. Endocrinol. 29:3-22.

Chilliard, Y., G. Gagliostro, J. Flechet, J. Lefaivre, and I. Sebastian. 1991. Duodenal rapeseed oil infusion in early and midlactation cows. 5. Milk fatty acids and adipose tissue lipogenic activities. J. Dairy Sci. 74:1844-1854.

Coleman, I. W., and J. M. R. Beveridge. 1960. The effect of dietary fat and the repeated withdrawal of small samples of blood on plasma cholesterol levels in the rat. J. Nutr. 71:303-309.

Coppock, C. E., and D. L. Wilks. 1991. Supplemental fat in highenergy rations for lactating cows: Effects on intake, digestion, milk yield, and composition. J. Anim. Sci. 69:3826-3837.

DePeters, E. J., S. J. Taylor, and R. L. Baldwin. 1989. Effect of dietary fat in isocaloric rations on the nitrogen content of milk from Holstein cows. J. Dairy Sci. 72:2949-2957.

Doepel, L., H. Lapierre, and J. J. Kennelly. 2002. Peripartum performance and metabolism of dairy cows in response to prepartum energy and protein intake. J. Dairy Sci. 85:2315-2334.

Douglas, G. N., T. R. Overton, H. G. Bateman II, H. M. Dann, and J. K. Drackley. 2006. Prepartal plane of nutrition, regardless of dietary energy source, affects periparturient metabolism and dry matter intake in Holstein cows. J. Dairy Sci. 89:2141-2157.

Douglas, G. N., T. R. Overton, H. G. Bateman, and J. K. Drackley. 2004. Peripartal metabolism and production of Holstein cows fed diets supplemented with fat during the dry period. J. Dairy Sci. $87: 4210-4220$.

Douglas, G. N., J. Rehage, A. D. Beaulieu, A. O. Bahaa, and J. K. Drackley. 2007. Prepartum nutrition alters fatty acid composition in plasma, adipose tissue, and liver lipids of peripaturient dairy cows. J. Dairy Sci. 90:2941-2959.

Drackley, J. K. 1999. Biology of dairy cows during the transition period: The final frontier? J. Dairy Sci. 82:2259-2273.

German Society of Nutrition Physiology. 2001. Ausschuss für Bedarfsnormen der Gesellschaft für Ernährungsphysiologie, No. 8 . Empfehlungen zur Energie- und Nährstoffversorgung der Milchkühe und Aufzuchtrinder (Recommended energy and nutrient supply for dairy cows and growing cattle). DLG-Verlag Frankfurt a. Main, Germany.

Goff, J. P., and R. L. Horst. 1997. Physiological changes at parturition and their relationship to metabolic disorders. J. Dairy Sci. 80:1260-1268.

Goldammer, T., H. Zerbe, A. Molenaar, H.-J. Schuberth, R. M. Brunner, S. R. Kata, and H.-M. Seyfert. 2004. Mastitis increases mammary mRNA abundance of $\beta$-defensin 5 , Toll-like-receptors 2 and 4 (TLR2, TLR4) but not TLR9 in cattle. Clin. Diagn. Lab. Immunol. 11:174-185.

Grum, D. E., J. K. Drackley, R. S. Younker, D. W. LaCount, and J. J. Veenhuizen. 1996. Nutrition during the dry period and hepatic lipid metabolism of periparturient dairy cows. J. Dairy Sci. 79:1850-1864.

Grummer, R. R. 1993. Etiology of lipid-related metabolic disorders in periparturient dairy cows. J. Dairy Sci. 76:3882-3896.

Grummer, R. R. 1995. Impact of changes in organic nutrient metabolism on feeding the transition dairy cow. J. Anim. Sci. 73:2820-2833.

Grummer, R. R., and D. J. Carroll. 1988. A review of lipoprotein cholesterol metabolism: Importance to ovarian function. J. Anim. Sci. 66:3160-3173.

Grummer, R. R., P. C. Hoffman, M. L. Luck, and S. J. Bertics. 1995. Effect of prepartum and postpartum dietary energy on growth and lactation of primiparous cows. J. Dairy Sci. 78:172-180.

Hachenberg, S., C. Weinkauf, S. Hiss, and H. Sauerwein. 2007. Evaluation of classification modes potentially suitable to identify metabolic stress in healthy dairy cows during the peripartal period. J. Anim. Sci. 85:1923-1932.

Hammon, H. M., C. C. Metges, P. Junghans, F. Becker, O. Bellmann, F. Schneider, G. Nürnberg, P. Dubreuil, and H. Lapierre. 2008. Metabolic changes and net portal flux in dairy cows fed a ration containing rumen-protected fat as compared to a control diet. J. Dairy Sci. 91:207-217.

Harvatine, K. J., and M. S. Allen. 2006. Effects of fatty acid supplements on feed intake, and feeding and chewing behavior of lactating dairy cows. J. Dairy Sci. 89:1104-1112.

Holtenius, K., S. Agenäs, C. Delavaud, and Y. Chilliard. 2003. Effects of feeding intensity during the dry period. 2. Metabolic and hormonal responses. J. Dairy Sci. 86:883-891.

Ingvartsen, K. L., and J. B. Andersen. 2000. Integration of metabolism and intake regulation: A review focusing on periparturient animals. J. Dairy Sci. 83:1573-1597.

Jenkins, T. C., and M. A. McGuire. 2006. Major advances in nutrition: Impact on milk composition. J. Dairy Sci. 89:1302-1310.

Kleppe, B. B., R. J. Aiello, R. R. Grummer, and L. E. Armentano. 1988. Triglyceride accumulation and very low density lipoprotein secretion by rat and goat hepatocytes in vitro. J. Dairy Sci. $71: 1813-1822$

Kuhla, S., M. Klein, U. Renne, W. Jentsch, P. E. Rudolph, and W. B. Souffrant. 2004. Carbon and nitrogen content based estimation of the fat content of animal carcasses in various species. Arch. Anim. Nutr. 58:37-46.

Lee, S. H., and K. L. Hossner. 2002. Coordinate regulation of ovine adipose tissue gene expression by propionate. J. Anim. Sci. 80:2840-2849

Lough, D. S., L. D. Muller, R. S. Kensinger, T. F. Sweeney, and L. C. Griel Jr. 1988. Effect of added dietary fat and bovine somatotropin on the performance and metabolism of lactating dairy cows. J. Dairy Sci. 71:1161-1169.

Mao, J., S. Marcos, S. K. Davis, and H.-M. Seyfert. 2001. Genomic arrangement of the three promoters expressing the bovine acetyl-CoA-carboxylase- $\alpha$-encoding gene and evidence that the nutritionally regulated PI contains a repressive element different from that in rat. Biochem. J. 358:127-135.

Mao, J., and H.-M. Seyfert. 2002. Promoter II of the bovine acetylcoenzyme A carboxylase $\alpha$-encoding gene is widely expressed and strongly active in different cells. Biochim. Biophys. Acta 1576:324-329

Mashek, D. G., and R. R. Grummer. 2003. Effects of long chain fatty acids on lipid and glucose metabolism in monolayer cultures of bovine hepatocytes. J. Dairy Sci. 86:2390-2396.

McNamara, J. P., J. H. Harrison, R. L. Kincaid, and S. S. Waltner. 1995. Lipid metabolism in adipose tissue of cows fed high fat diets during lactation. J. Dairy Sci. 78:2782-2796.

Moallem, U., A. Arieli, and H. Lehrer. 2007a. Effects of prepartum propylene glycol or fats differing in fat acid profiles on feed intake, production, and plasma metabolites in dairy cows. J. Dairy Sci. 90:3846-3856.

Moallem, U., M. Katz, H. Lehrer, L. Livshitz, and S. Yakoby. 2007b. Role of peripartum dietary propylene glycol or protected fats on metabolism and early postpartum ovarian follicles. J. Dairy Sci. 90:1243-1254. 
Moibi, J. A., E. D. Ekpe, and R. J. Christopherson. 2000. Acetyl-CoA carboxylase and fatty acid synthase activity and immunodetectable protein in adipose tissues of ruminants: Effect of temperature and feeding level. J. Anim. Sci. 78:2383-2392.

Naumann, C., and R. Bassler. 1993. Die chemische Untersuchung von Futtermitteln. VDLUFA-Verlag, Darmstadt, Germany.

Nestel, P. J., A. Poyser, R. L. Hood, S. C. Mills, M. R. Willis, L. J. Cook, and T. W. Scott. 1978. The effect of dietary fat supplements on cholesterol metabolism in ruminants. J. Lipid Res. 19:899909.

Palmquist, D. L., A. D. Beaulieu, and D. M. Barbano. 1993. Feed and animal factors influencing milk fat composition. J. Dairy Sci. $76: 1753-1771$.

Palmquist, D. L., and H. R. Conrad. 1978. High fat rations for dairy cows. Effects on feed intake, milk and fat production, and plasma metabolites. J. Dairy Sci. 61:890-901.

Petit, H. V., M. F. Palin, and L. Doepel. 2007. Hepatic lipid metabolism in transition dairy cows fed flaxseed. J. Dairy Sci. 90:4780-4792.

Ponce-Castaneda, M. V., F. Lopez-Casillas, and K.-H. Kim. 1991. Acetyl-coenzyme A carboxylase messenger ribonucleic acid metabolism in liver, adipose tissue, and mammary glands during pregnancy and lactation. J. Dairy Sci. 74:4013-4021.

Radcliff, R. P., B. L. McCormack, B. A. Crooker, and M. C. Lucy. 2003. Growth hormone (GH) binding and expression of $\mathrm{GH}$ receptor $1 \mathrm{~A}$ mRNA in hepatic tissue of periparturient dairy cows. J. Dairy Sci. 86:3933-3940.

Reist, M., D. K. Erdin, D. van Euw, K. M. Tschuemperlin, H. Leuenberger, C. Delavaud, Y. Chilliard, H. M. Hammon, N. Kuenzi, and J. W. Blum. 2003. Concentrate feeding strategy in lactating dairy cows: Metabolic and endocrine changes with emphasis on leptin. J. Dairy Sci. 86:1690-1706.

SAS Institute. 1999. SAS User's Guide: Statistics. Version 8.2 ed. SAS Institute Inc., Cary, NC.

Sauerwein, H., U. Heintges, M. Hennies, T. Selhorst, and A Daxenberger. 2004. Growth hormone induced alterations of leptin serum concentrations in dairy cows as measured by a novel enzyme immunoassay. Livest. Prod. Sci. 87:189-195.

Schröder, U. J., and R. Staufenbiel. 2006. Invited review: Methods to determine body fat reserves in the dairy cow with special regard to ultrasonographic measurement of backfat thickness. J. Dairy Sci. $89: 1-14$

Skaar, T. C., R. R. Grummer, M. R. Dentine, and R. H. Stauffacher. 1989. Seasonal effects of prepartum and postpartum fat and niacin feeding on lactation performance and lipid metabolism. J. Dairy Sci. 72:2028-2038.

Sumner, J., C. Shachtschneider, J. Vierck, and J. McNamara. 2008. Changes in the transcriptome of adipose tissue of the dairy heifer during late pregnancy and lactation as measured by gene array analysis: Changes in specific metabolic control genes. J. Dairy Sci. 91(E. Suppl. 1):313. (Abstr.)

Sutton, J. D. 1985. Digestion and absorption of energy substrates in the lactating cow. J. Dairy Sci. 68:3376-3393.

Thorn, S. R., M. J. Meyer, M. E. Van Amburgh, and Y. R. Boisclair. 2007. Effect of estrogen on leptin and expression of leptin receptor transcripts in prepubertal dairy heifers. J. Dairy Sci. 90:37423750 .

Vandehaar, M. J., G. Yousif, B. K. Sharma, T. H. Herdt, R. S. Emery, M. S. Allen, and J. S. Liesman. 1999. Effect of energy and protein density of prepartum diets on fat and protein metabolism of dairy cattle in the periparturient period. J. Dairy Sci. 82:1282-1295.

Van Knegsel, A. T. M., H. Van den Brand, J. Dijkstra, W. M. Van Straalen, M. J. W. Heetkamp, S. Tamminga, and B. Kemp. 2007. Dietary energy source in dairy cows in early lactation: Energy partitioning and milk composition. J. Dairy Sci. 90:1467-1476.

Vazquez-Añon, M., S. J. Bertics, and R. R. Grummer. 1997. The effect of dietary energy source during mid to late lactation on liver triglyceride and lactation performance of dairy cows. J. Dairy Sci. $80: 2504-2512$

Vazquez-Añon, M., S. J. Bertics, M. Luck, R. R. Grummer, and J. Pinheiro. 1994. Peripartum liver triglyceride and plasma metabolites in dairy cows. J. Dairy Sci. 77:1521-1528.

Vernon, R. G. 2005. Lipid metabolism during lactation: A review of adipose tissue-liver interactions and the development of fatty liver. J. Dairy Res. 72:460-469

Voigt, J., S. Kuhla, K. Gaafar, M. Derno, and H. Hagemeister. 2006. Digestibility of rumen protected fat in cattle. Slovak J. Anim. Sci. 39:16-19. 